\title{
Detection of Pythium ultimum Using Polymerase Chain Reaction with Species-Specific Primers
}

\author{
K. Kageyama, Faculty of Agriculture, Gifu University, Gifu 501-11, Japan; A. Ohyama, National Research Insti- \\ tute of Vegetables, Ornamental Plants and Tea, Ano, Mie 514-23, Japan; and M. Hyakumachi, Faculty of Agricul- \\ ture, Gifu University, Gifu 501-11, Japan
}

\begin{abstract}
Kageyama, K., Ohyama, A., and Hyakumachi, M. 1997. Detection of Pythium ultimum using polymerase chain reaction with species-specific primers. Plant Dis. 81:1155-1160.

This study was conducted to sequence the rDNA internal transcribed spacer (ITS) region of Pythium ultimum and Pythium group HS, design species-specific primers for polymerase chain reaction (PCR), and detect $P$. ultimum from diseased seedlings using PCR. The sequence of the ITS region of $P$. ultimum was identical with that of Pythium group HS. The results support the reports that the HS group is an asexual strain of P. ultimum. Using PCR, the primer pair $\mathrm{K} 1+\mathrm{K} 3$, designed on portions of the sequence of the ITS region, amplified isolates of $P$. ultimum and the HS group but not isolates of 20 other Pythium species. DNA extracts from damped-off seedlings were not amplified, but a 10-fold dilution of the extracts with Tris-EDTA (TE) buffer diluted the inhibitors and allowed PCR amplification. The primer pair used detected P. ultimum from a single diseased seedling.
\end{abstract}

The genus Pythium consists of more than 120 species (11). The identification keys provided by Plaats-Niterink (34) and Dick (11) are commonly used by many workers. The major structural features, such as the size of oogonia and oospores, the morphology of oogonia, antheridia, and sporangia, and the growth habit and rate on culture medium can be characterized. However, it is difficult to determine the detailed features, such as antheridial branch origin, antheridial attachment, and plerotic or aplerotic status of oospores, which vary under different cultural conditions (16). Therefore, the identification of some Pythium species is very difficult. The use of a selective medium is well established for isolating many species from soil or diseased tissue $(1,18,21)$. However, if the population density of a specific species is to be estimated, the colonies that appear on the selective medium must be individually transferred to culture media for identification. Problems of identification and quantification have limited the study of the ecology of Pythium species and the diagnosis of species responsible for diseases.

DNA probes have been developed for identification of Pythium species $(22,26,30)$.

Corresponding author: K. Kageyama

E-mail: kageyama@cc.gifu-u.ac.jp

Current address of A. Ohyama: Plant Breeding and Genetics Research Institute, Japan Tobacco Inc., Iwata, Shizuoka 438, Japan

Accepted for publication 17 June 1997.

Publication no. D-1997-0805-01R

(C) 1997 The American Phytopathological Society
The polymerase chain reaction (PCR) for amplification of diagnostic molecular markers is highly sensitive and reproducible, and could easily be used for identification and detection if species-specific primers were designed. Such a technique has been used to identify fungi, including Acremonium coenophialum (12), Fusarium spp. (37), Gaeumannomyces graminis (17), Monosporascus spp. (28), Septoria tritici and Stagonospora nodorum (4), and Verticillium spp. $(31,32)$. Nuclear rDNA consists of the small and large subunits, $5.8 \mathrm{~S}$, and the internal transcribed spacer (ITS) region in fungi, and each sequence is variable at the family, genus, or species level. In Pythium, the ITS region is variable at the species level (6-8). The number of copies of the rDNA repeat is usually more than 50 per genome, suggesting a possible high sensitivity for detection if used as a target gene for PCR. Thus, the ITS region of rDNA may be valuable for detection of individual species of Pythium using PCR amplification.

Pythium ultimum Trow is a widespread and important plant pathogen causing damping-off and root rot in many plant species (15). The HS group, according to the identification key of Plaats-Niterink (34), is reported to be an asexual strain of P. ultimum $(13,29,36)$.

In this study, we report the sequence of the ITS region of the rDNA of $P$. ultimum and group HS, the design of species-specific primers for PCR, and a procedure for detection of $P$. ultimum from diseased plants using PCR.

\section{MATERIALS AND METHODS}

Isolates and DNA extraction from mycelia. Isolates of Pythium used in this study are listed in Table 1. The cultures were maintained on cornmeal agar at $25^{\circ} \mathrm{C}$. For DNA extraction, three agar plugs were removed from the growing margin of 2day-old cultures on potato carrot agar with a $1-\mathrm{cm}$ cork borer and transferred to $20 \%$ V8 juice broth containing $2.5 \mathrm{~g}$ of $\mathrm{CaCO}_{3}$ per liter. Mycelial mats were collected on filter paper placed in a Buchner funnel after a 3- to 4-day incubation period at $25^{\circ} \mathrm{C}$ and rinsed several times with distilled water. After excess water was removed with filter paper, the mycelial mats were frozen at $-80^{\circ} \mathrm{C}$ for more than 1 day and powdered by using a sterilized, prefrozen mortar and pestle. The extraction of DNA was conducted according to the procedure of Lee and Taylor (24), except for precipitating DNA with $99.8 \%$ cold ethanol. The DNA was dissolved in $200 \mu \mathrm{l}$ of TE buffer (10 mM Tris-HCl, pH 8.0, and 0.1 mM EDTA.

PCR procedure. The universal and the designed primers in the present study (Table 2) were used to amplify the ITS region as described by White et al. (41). A total volume of $25 \mu \mathrm{l}$ of reaction mixture contained $1 \mu \mathrm{M}$ of each primer, 1.25 units of rTaq DNA polymerase (Takara Shuzo Co. Ltd., Shiga, Japan), $0.2 \mathrm{mM}$ dNTP mixture, $1 \times$ PCR buffer (10 mM Tris- $\mathrm{HCl}$, $\mathrm{pH} 8.3,50 \mathrm{mM} \mathrm{KCl}$, and $1.5 \mathrm{mM} \mathrm{MgCl}_{2}$ ), and 100 to $300 \mathrm{ng}$ of DNA template. The reaction was conducted using a DNA thermal cycler (Perkin-Elmer Cetus Instruments, Norwalk, CT), and the amplification condition was an initial denaturation at $94^{\circ} \mathrm{C}$ for $3 \mathrm{~min}$, followed by 25 cycles of denaturation at $94^{\circ} \mathrm{C}$ for $1 \mathrm{~min}$, annealing at $55^{\circ} \mathrm{C}$ for $1 \mathrm{~min}$, and extension at $72^{\circ} \mathrm{C}$ for 2 min with final extension at $72^{\circ} \mathrm{C}$ for 10 min. PCR products were precipitated with cold ethanol, and their size was examined by electrophoresis for $60 \mathrm{~min}$ in 1.2\% Agarose LO3 (Takara Shuzo Co. Ltd., Shiga, Japan) gel. Gels were stained with ethidium bromide and photographed under ultraviolet light.

Sequencing PCR products. The amplified ITS fragments from P. ultimum, Py79, and the HS group, Py55, were cloned using the TA Cloning Kit and pCRII vector (Invitrogen Corporation, San Diego, CA). The DNA sequences of the ITS regions were determined by the method of Sanger et al. (35) using an automated sequencer (Applied Biosystems, model 373A, Foster City, CA). DNA sequences were analyzed 
using a software from GENETYX (Software Development Co. Ltd., Tokyo, Japan).

DNA extraction from damped-off seedlings. Three plant species, Chinese cabbage (Brassica campestris var. chinensis (L.) Makino cv. Muso), cucumber (Cucumis sativus L. cv. Jibai), and sugar beet (Beta vulgaris L. var. saccharifera Alef. cv. Monoace), were grown either in a potting soil mix (Starbed, Kyodouhiryo Co. Ltd., Japan) infested with a mycelial suspension of $P$. ultimum as described by Kageyama and Ui (20), or in soil naturally infested with $P$. ultimum as well as several other Pythium species. The naturally infested soil was collected from a Chinese cabbage field in Gifu, Japan. Twenty seeds were planted in pots $(5 \mathrm{~cm}$ diameter) and were incubated in a growth chamber at 20 to $25^{\circ} \mathrm{C}$. Seedlings showing damping-off symptoms were immediately taken from the pots. Healthy plants were collected 2 weeks after seeding. A water-soaked lesion of a damped-off seedling and a hypocotyl of a healthy seedling were cut into two sections and used for DNA extraction and for isolation of Pythium species, respectively, after washing the diseased seedling under tap water. The preparation of the specimens before DNA extraction was done using two methods: (i) macerating the specimens frozen at $-80^{\circ} \mathrm{C}$ with a sterilized, prefrozen mortar and pestle; and (ii) cutting the specimens into approximately $1-\mathrm{mm}$ pieces. DNA was extracted using the DNA extraction kit (ISOPLANT, Nippon Gene Co. Ltd., Toyama, Japan), which had benzyl chloride as a main component, following the manufacturer's instructions.
The DNA was dissolved in $20 \mu \mathrm{l}$ of TE buffer and diluted 0- to 100-fold with TE buffer before PCR amplification.

Southern hybridization. PCR products were separated by electrophoresis in a $1.5 \%$ agarose gel and transferred onto a nucleic acid transfer nylon membrane (Hybond $\mathrm{N}+$, Amersham International plc, Amersham, UK) by alkaline transfer in 0.4 $\mathrm{M} \mathrm{NaOH}$. A hybridization probe was produced from the PCR product of $P$. ultimum, Py79 isolate, and labeled with digoxigenin (Boehringer Mannheim, Indianapolis, IN). The hybridization and detection was performed with the Dig nucleic acid detection kit (Boehringer Mannheim). Both procedures were done according to the manufacturer's instruction.

Isolation of $P$. ultimum from dampedoff plants. A portion of the water-soaked

Table 1. Polymerase chain reaction (PCR) amplification of the internal transcribed spacer (ITS) region of Pythium species using universal and speciesspecific primers

\begin{tabular}{|c|c|c|c|c|c|}
\hline \multirow[b]{2}{*}{ Species } & \multirow[b]{2}{*}{ Isolates } & \multirow[b]{2}{*}{ Host/habitat } & \multirow[b]{2}{*}{ Geographic origin } & \multicolumn{2}{|c|}{ PCR products } \\
\hline & & & & ITS $^{\mathbf{a}}$ & $\mathbf{S S}^{\mathbf{b}}$ \\
\hline P. ultimum & MK2-2-1V & Bent grass green soil & Gifu, Japan & + & + \\
\hline P. ultimum & OF231 & Carrot field soil & Gifu, Japan & + & + \\
\hline P. ultimum & Py 79 & Sugar beet & Hokkaido, Japan & + & + \\
\hline P. ultimum & UOP358 & Chinese cabbage & Sendai, Japan & + & + \\
\hline Group HS & BeBS 2 & Kidney bean field soil & Hokkaido, Japan & + & + \\
\hline Group HS & Py 55 & Sugar beet & Hokkaido, Japan & + & + \\
\hline Group HS & SoyBS 13 & Soybean field soil & Hokkaido, Japan & + & + \\
\hline Group HS & $18-3$ & Carrot field soil & Gifu, Japan & + & + \\
\hline P. aphanidermatum & UOP390 & Spinach & Osaka, Japan & + & - \\
\hline P. aphanidermatum & TOc159 & Carrot field soil & Gifu, Japan & + & - \\
\hline P. arrhenomanes & GUP6 & Sugarcane & Kagoshima, Japan & + & - \\
\hline P. arrhenomanes & GUP7 & Sugarcane & Kagoshima, Japan & + & - \\
\hline P. catenulatum & ATCC 10950 & & & + & - \\
\hline P. catenulatum & MK4-10-2S & Zoysia grass & Gifu, Japan & + & - \\
\hline P. chamaehyphon & MS6-10-8V & Forest soil & Gifu, Japan & + & - \\
\hline P. coloratum & TM321 & Carrot & Gifu, Japan & + & - \\
\hline P. coloratum & $\mathrm{Z} 712$ & Carrot & Gifu, Japan & + & - \\
\hline P. graminicola & $32-1 \mathrm{sh}$ & Zoysia grass & Japan & + & - \\
\hline P. graminicola & TS2 & Sugarcane & Kagoshima, Gifu & + & - \\
\hline P. irregulare & Py 66 & Sugar beet & Hokkaido, Japan & + & - \\
\hline P. irregulare & 6K4SSDP & Zoysia grass coarse soil & Gifu, Japan & + & - \\
\hline P. iwayamai & MK1-2-18V & Zoysia grass coarse soil & Gifu, Japan & + & - \\
\hline P. iwayamai & MK4-6-5S & Zoysia grass & Gifu, Japan & + & - \\
\hline P. myriotylum & BeAT1 & Kidney bean & Hokkaido, Japan & + & - \\
\hline P. myriotylum & BeBT1 & Kidney bean & Hokkaido, Japan & + & - \\
\hline P. orthogonon & DS2-6-9D & Zoysia grass & Gifu, Japan & + & - \\
\hline P. orthogonon & MS1-9-2S & Zoysia grass & Gifu, Japan & + & - \\
\hline P. paroecandrum & ATCC36784 & Barley & United States & + & - \\
\hline P. paroecandrum & BeA-7 & Kidney bean & Hokkaido, Japan & + & - \\
\hline P. periilum & MK4-8-11V & Zoysia grass coarse soil & Gifu, Japan & + & - \\
\hline P. periilum & S2-8-1S & Zoysia grass & Gifu, Japan & + & - \\
\hline P. periplocum & DS1-7-2S & Zoysia grass & Gifu, Japan & + & - \\
\hline P. periplocum & DK1-5-1S & Zoysia grass & Gifu, Japan & + & - \\
\hline$P$. rostratum & DS5-7-1S & Bent grass & Gifu, Japan & + & - \\
\hline P. rostratum & MK2-1-9S & Bent grass & Gifu, Japan & + & - \\
\hline$P$. spinosum & Py 75 & Sugar beet & Hokkaido, Japan & + & - \\
\hline P. spinosum & TN254 & Carrot & Gifu, Japan & + & - \\
\hline P. splendens & ATCC42852 & Luculia gratissima & New Zealand & + & - \\
\hline$P$. sulcatum & CTMa7 & Carrot & Gifu, Japan & + & - \\
\hline P. sulcatum & GUP2 & Carrot & Gifu, Japan & + & - \\
\hline P. sylvaticum & Py 35 Ho-M & Sugar beet & Hokkaido, Japan & + & - \\
\hline P. sylvaticum & S66-4-8 & Kidney bean & Hokkaido, Japan & + & - \\
\hline P. torulosum & $52-1 \mathrm{sz}-1$ & Zoysia grass & Kyoto, Japan & + & - \\
\hline P. torulosum & TJu143 & Carrot & Gifu, Japan & + & - \\
\hline P. vanterpoolii & DK1-6-3D & Zoysia grass coarse soil & Gifu, Japan & + & - \\
\hline$P$. vanterpoolii & UOP392 & Zoysia grass & Japan & + & - \\
\hline
\end{tabular}

a Universal primer set, ITS1+ITS4, was used. The + indicates that PCR product (910 bp) is obtained.

${ }^{b}$ Potential species-specific primer set, $\mathrm{K} 1+\mathrm{K} 3$, was used. The + indicates that PCR product $(670 \mathrm{bp})$ is obtained. 
lesion left after DNA extraction was directly plated on a Pythium selective medium (19) consisting of $17 \mathrm{~g}$ of Difco cornmeal agar, $5 \mathrm{mg}$ of pimaricin, $100 \mathrm{mg}$ of pentachloronitrobenzene, and $100 \mathrm{mg}$ of agrimycin per liter. Plates were incubated at $25^{\circ} \mathrm{C}$ in the dark for 2 to 6 days. Isolates were identified according to the key of Plaats-Niterink (34).

\section{RESULTS}

Sequence of the ITS region of $P$. ultimum. The sequence of the ITS region of $P$. ultimum (Py79) was identical with that of the isolate of HS group (Py55). PCR products consisted of $3^{\prime}$ ends of $18 \mathrm{~S}$ rDNA, ITSa region, 5.8S rDNA, ITSb region, and $5^{\prime}$ ends of 28S rDNA with 914 bp (Fig. 1).

Primer design and specificity to $P$. $u l$ timum. The three primers shown in Figure 1 and Table 2 were synthesized and designated K1, K2, and K3. Because the ITSa has interspecific differences in Pythium species and the center of the ITSb is not species-specific (26), the primers were designed in the center of the ITSa and downstream of the ITSb or the $5^{\prime}$ ends of $28 \mathrm{~S}$ rDNA. The six possible combinations of the primers, $\mathrm{K} 1+\mathrm{K} 2, \mathrm{~K} 1+\mathrm{K} 3, \mathrm{~K} 1+\mathrm{ITS} 4$, $\mathrm{ITS} 1+\mathrm{K} 2$, ITS1+K3, and ITS1+ITS4, were compared to examine the specificity to $P$. ultimum (Py79), HS group (Py55), P. syl- vaticum (Py35), and P. irregulare (Py61). Four primer combinations, $\mathrm{K} 1+\mathrm{K} 2$, $\mathrm{K} 1+\mathrm{K} 3$, K1+ITS4, and ITS1+K3, did not produce PCR products for $P$. sylvaticum and $P$. irregulare. In P. ultimum and HS group isolates, the ITS region was amplified with all primer combinations, suggesting that $\mathrm{K} 1$ and $\mathrm{K} 3$ may be speciesspecific.

A total of 46 isolates representing 21 Pythium species and the HS group were used to test the species-specificity of primer combination $\mathrm{K} 1+\mathrm{K} 3$ to $P$. ultimum (Table 1). PCR products, 910 and $670 \mathrm{bp}$, were obtained in each combination of universal primers (ITS1+ITS4) and potential specific primers $(\mathrm{K} 1+\mathrm{K} 3)$, respectively, for four isolates each of P. ultimum and the HS group obtained from different host plants or soils collected in geographically different locations in Japan. However, for the isolates representing the other species, PCR amplification products $(910 \mathrm{bp})$ were found only for the primer combination, ITS1+ITS4.

Detection of $P$. ultimum in DNA extracts from damped-off seedlings using PCR amplification. DNA was extracted from five damped-off seedlings each of cucumber, sugar beet, and Chinese cabbage grown in soil artificially infested with $P$. ultimum. The hypocotyls with roots were frozen at $-80^{\circ} \mathrm{C}$ and then macerated with a sterilized, prefrozen mortar and pestle. PCR products (670 bp) from initial DNA extracts were not detected by electrophoresis or Southern hybridization, except in cucumber (Fig. 2). However, when the DNA extracts were diluted 10- and even 100-fold with TE buffer, distinct bands for the pathogen were observed for cucumber, sugar beet, and Chinese cabbage. The DNA extracts were diluted 10-fold with TE buffer in subsequent experiments. PCR amplification was performed twice for each DNA extract, and the same results were obtained.

Plants of each of the three species showing damped-off symptoms in artificially infested soil were prepared by macerating one or five frozen lesions $\left(-80^{\circ} \mathrm{C}\right)$ with a sterilized, prefrozen mortar and pestle or by cutting one lesion into approximately $1-\mathrm{mm}$ pieces. The bands $(670$ bp) were observed from the DNA extracts,

Table 2. Primer sequence

\begin{tabular}{ll}
\hline Primer & Sequence \\
\hline ITS1 & TCCGTAGGTGAACCTGCGG \\
ITS4 & TCCTCCGCTTATTGATATGC \\
K1 & ACGAAGGTTGGTCTGTTG \\
K2 & TCTTGTCTGATATCAGGTC \\
K3 & TCTCTACGCAACTAAATGC \\
\hline
\end{tabular}

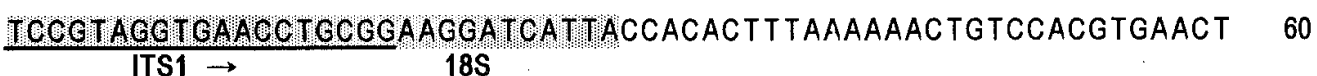

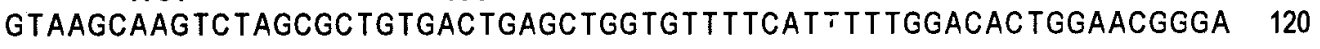

GTCAGCAGGACGAAGGTTGGTCTGTTGTAATGCAAGTTATGATGGACTAGCTGATGAACT 180 $\mathrm{K} 1 \rightarrow$

TTTGTTTTTAAACCCTTACCTAAATACTGATTTATACTGTGgGGACGAAAGTCCTTGCTT 240

TTACTAGATAACAACTTTCAGCAGTGGATGTCTAGGOTCGCACATCGATGAAGAACGCTG 300

CGAACTGCGATACGIAATGCGAAT TGCAGAATTCAGTGAGTCATCGAAATIT TGAAGGCA 360 $5.8 \mathrm{~S}$

TAT TGCAGTTTCGGGTTATECCTGGAAGTATGTCTGTATCAGTGTCCGTAAATCAAACTT 420

GCCTTTCTTTTTCTGTGTAGTCAGgGATGgAATGTGCAGATGTGAAGTGTCTCGCATGgT 480

TGCGTTCGTTTTTTCGATCGAGAATCTGTCGAGTCCTTTTAAATGGACACGgTCTTTTCT 540

ATGGTTTCTATGAAGTGTAATGGT TGgAATGCAGTGATTTICGGATTGCTGGCGGCTTTT 600

GGCGACTTCGGTATGAACGTATGGAGACTAGCTCAATTCGTGGTATGTTAGGCTTCGGCT 660

CGACAATGTTGCGTAATTGTGTGTGGTCTTTGTTIGTGCCTTGAGGTGTACTAGAGGTTG 720

TCGgTTTGAACCGTAAGTGATTGTTTAGTAGAGCATTTTCACGATGTATGGAGACGCT $\underline{\underline{C}} 780$

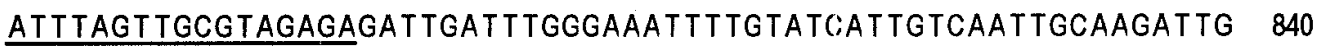
$\div \mathrm{K} 3$

TGTATGGTATCTCAATTGGACCTGATATCAGACAAGACTACCCGCTGAACTTAAGCATAT 990

CAATAAGGGGAGGA

$\leftarrow \mathrm{K} 2 \quad 28 \mathrm{~S}$

$\leftarrow$ ITS4

Fig. 1. Sequence of the rDNA internal transcribed spacer (ITS) region of Pythium ultimum isolate Py79 and Pythium group HS isolate Py55. The sequences were completely identical for the two isolates. The amplified DNA consists of $3^{\prime}$ end of $18 \mathrm{~S}$ rDNA, ITSa, 5.8S rDNA, ITSb, and 5' end of 28S rDNA. ITS1 and ITS 4 are universal primers, and K1, K2, and K3 are selected as primers in the present experiments. The accession number of the DDBJ databases is D86515. 
both from a single seedling and from five damped-off seedlings of all plant species, by means of Southern hybridization, but not from a single seedling of Chinese cabbage for electrophoresis. When preparation methods of the specimens before DNA extraction were compared, the bands from PCR products amplified from diluted DNA extracts were observed in Southern hybridization regardless of the preparation method used (Fig. 3). PCR amplification was performed twice for each DNA extract with the same results.

Ten damped-off seedlings each of cucumber, sugar beet, and Chinese cabbage in naturally infested soil were used to compare detection of $P$. ultimum by isolation from lesions on selective medium and PCR with the species-specific primers (Table 3). In three to five repeated experiments, the disease incidence averaged 6.5, 11.9 , and $19.2 \%$ for cucumber, sugar beet, and Chinese cabbage, respectively. For DNA extraction, the specimens were prepared by cutting one lesion to approximately $1 \mathrm{~mm}$ in length. In cucumber, $P$. ultimum was recovered from 10 seedlings, and the bands (670 bp) were observed from all of the diseased seedlings in Southern hybridization, although not from a single seedling in electrophoresis. In sugar beet, amplification was observed in seven damped-off seedlings from which $P$. ultimum was isolated, in one seedling from which another Pythium species was isolated, and in one seedling from which no Pythium was isolated in either electrophoresis or Southern hybridization. In Chinese cabbage, the bands in electrophoresis were observed in four diseased seedlings from which P. ultimum was isolated, while the signals in Southern hybridization were obtained in all of five damped-off seedlings from which P. ultimum was isolated and in a single seedling from which another Pythium species was obtained. No amplification occurred when DNA extracts from healthy plants of three plant species were used. PCR amplification was performed twice for each DNA extract with the same results.

\section{DISCUSSION}

The ITS region of the rDNA is highly conserved within a fungal species but not between species (41). With Pythium species, restriction fragment length polymorphism (RFLP) analysis has been used to distinguish species $(6,8)$. In the present study, the sequence of the ITS region of $P$. ultimum was identical with that of the HS group. This supports other lines of evidence that the HS group is an asexual strain of $P$. ultimum that includes restriction patterns of mitochondrial DNA (29) and the ability to outcross $(13,36)$.

Information is available on DNA sequences of the ITS region in fungi. These include sequencing the region for Phytophthora spp. (25), Fusarium sambucinum

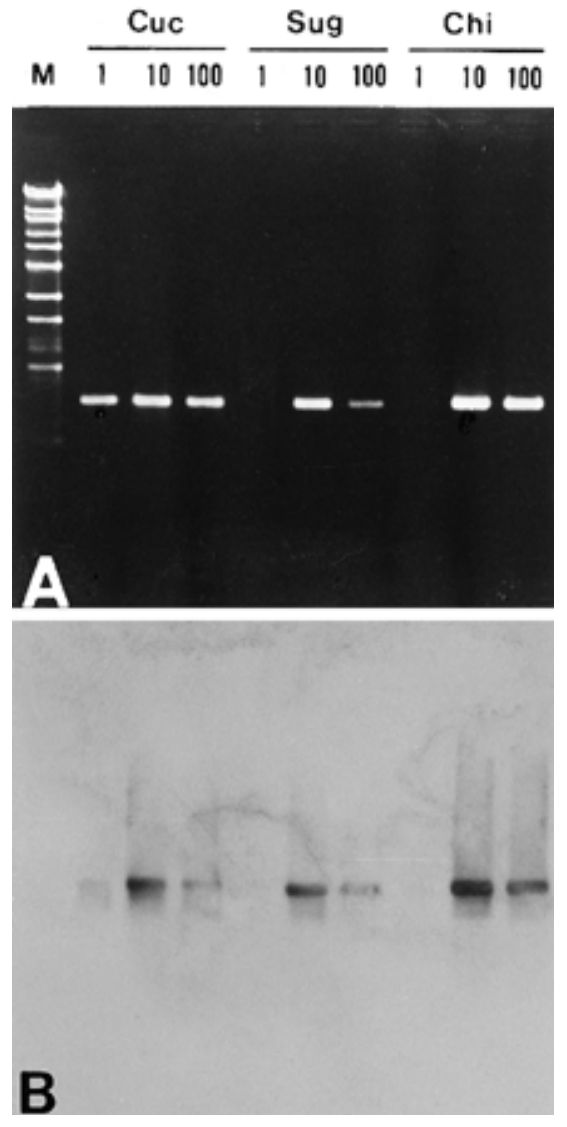

Fig. 2. Polymerase chain reaction (PCR) amplification of diluted and nondiluted DNA extracts from seedlings exhibiting damping-off symptoms in soil artificially infested with Pythium ultimum using species-specific primers. Seedlings of cucumber (Cuc), sugar beet (Sug), and Chinese cabbage (Chi) were used. The DNA extracts were not (1), 10-fold (10), and 100-fold (100) diluted with TE buffer. Lane M: size marker from StylI digestion of bacteriophage lambda. (A) Agarose gel electrophoresis; (B) Southern hybridization using the digoxigeninlabeled probe from the PCR product of P. ultimum

(33), Metarhizium spp. (9), Colletotrichum spp. (38,40), Gaeumannomyces graminis (14), and Septoria tritici and Stagonospora nodorum (4). The sequence of the region described in the present study is an initial finding in the genus Pythium. The restriction sites based on the sequence of the ITS region were similar to those described by Levesque et al. (26) and Chen et al. (8), suggesting that the isolates used in the present study would be closely related to isolates from other parts of the world. The determined sequence showed little homology with previously identified sequences of other fungi registered in the DDBJ and GeneBank databases. The nucleotide sequence data reported in this paper will appear in the DDBJ database under accession number D86515.

Few studies have reported the detection of a pathogen from naturally infected plants (5). This might be due to inhibitors to PCR amplification such as humic acids (23). Hypocotyls and roots showing rot

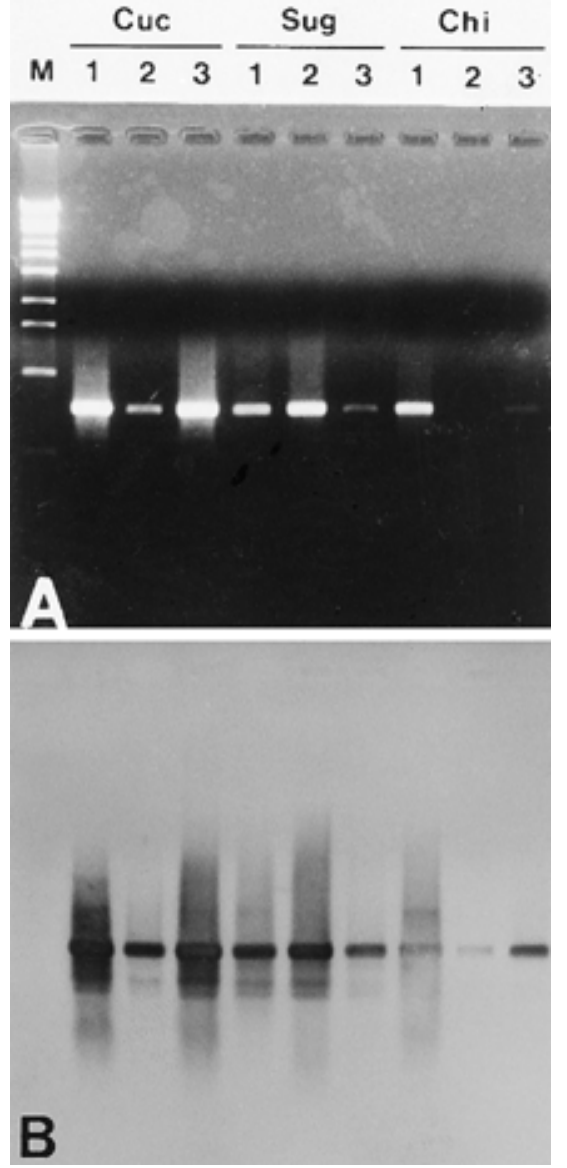

Fig. 3. The effect of preparation methods of damped-off seedling materials for DNA extraction on detection of Pythium ultimum by polymerase chain reaction (PCR) with speciesspecific primers. The seedlings of cucumber (Cuc), sugar beet (Sug), and Chinese cabbage (Chi) were collected from soil artificially infested with $P$. ultimum. The preparation of the seedlings was conducted by macerating five (lane 1) and one (lane 2) seedlings frozen at $-80^{\circ} \mathrm{C}$ with a sterilized, prefrozen mortar and pestle, respectively, and by cutting one seedling into approximately $1-\mathrm{mm}$ pieces (lane 3 ). Lane M: the size marker from Styll digestion of bacteriophage lambda. (A) Agarose gel electrophoresis; (B) Southern hybridization using the digoxigenin-labeled probe from the PCR product of P. ultimum.

symptoms collected from soil will potentially contain humic acids, and in this study these portions were used for DNA extraction. Initial attempts to amplify the ITS region of the rDNA from diseased seedlings suggested the presence of inhibitors. However, PCR products were detected from seedlings naturally infected with $P$. ultimum following dilution of the extracted DNA with TE buffer, suggesting that dilution can overcome the effects of inhibitors.

Immunological techniques have also been developed to detect plant pathogens $(2,3,42)$. Monoclonal antibodies recognize a single epitope on a protein; therefore its specificity is as high as that of the PCR technique using specific primers $(10,27,39)$. However, if a researcher should decide to conduct similar experiments, the 
Table 3. Detection of Pythium ultimum from damped-off seedlings in naturally infested soil by polymerase chain reaction (PCR) with species-specific primers

\begin{tabular}{|c|c|c|c|}
\hline \multirow{2}{*}{$\begin{array}{l}\text { Damped-off } \\
\text { seedlings }\end{array}$} & \multirow{2}{*}{$\begin{array}{l}\text { Isolation of } \\
\text { Pythium }^{\text {a }}\end{array}$} & \multicolumn{2}{|c|}{ Bands $^{\mathrm{b}}$} \\
\hline & & Electrophoresis & Southern blotting ${ }^{\mathrm{c}}$ \\
\hline \multicolumn{4}{|l|}{ Cucumber } \\
\hline Healthy & & - & - \\
\hline 1 & P. ultimum & + & + \\
\hline 2 & P. ultimum & + & + \\
\hline 3 & P. ultimum & + & + \\
\hline 4 & P. ultimum & + & + \\
\hline 5 & P. ultimum & + & + \\
\hline 6 & P. ultimum & + & + \\
\hline 7 & P. ultimum & + & + \\
\hline 8 & P. ultimum & + & + \\
\hline 9 & P. ultimum & - & + \\
\hline 10 & P. ultimum & + & + \\
\hline \multicolumn{4}{|l|}{ Sugar beet } \\
\hline Healthy & $\ldots$ & - & - \\
\hline 1 & P. ultimum & + & + \\
\hline 2 & P. ultimum & + & + \\
\hline 3 & P. ultimum & + & + \\
\hline 4 & P. ultimum & + & + \\
\hline 5 & P. ultimum & + & + \\
\hline 6 & P. ultimum & + & + \\
\hline 7 & P. ultimum & + & + \\
\hline 8 & Pythium sp. & - & - \\
\hline 9 & Pythium sp. & + & + \\
\hline 10 & $\ldots$ & + & + \\
\hline \multicolumn{4}{|c|}{ Chinese cabbage } \\
\hline Healthy & . & - & - \\
\hline 1 & P. ultimum & + & + \\
\hline 2 & P. ultimum & + & + \\
\hline 3 & P. ultimum & + & + \\
\hline 4 & P. ultimum & + & + \\
\hline 5 & P. ultimum & - & + \\
\hline 6 & Pythium sp. & - & + \\
\hline 7 & Pythium sp. & - & - \\
\hline 8 & Pythium sp. & - & - \\
\hline 9 & Pythium sp. & - & - \\
\hline 10 & Pythium sp. & - & - \\
\hline
\end{tabular}

${ }^{a}$ A portion of the lesion used for DNA extraction was plated on Pythium selective medium. The colony was transferred and identified.

${ }^{\mathrm{b}}$ The probe was produced by labeling the PCR products from P. ultimum with digoxigenin-11-dUTP.

c The size of the band was $670 \mathrm{bp}$.

antibody must be provided by the original researcher. In PCR, if the primer sequences are available, the primers can be synthesized independently, and the same method could be followed by any researcher.

In the present study, the combination of the primers, $\mathrm{K} 1+\mathrm{K} 3$, is species-specific to $P$. ultimum and will selectively amplify DNA from isolates of $P$. ultimum and HS group but not from other isolates of $P y$ thium species. In addition, the use of the primer pair could detect $P$. ultimum from single diseased seedlings. Further study is needed to develop a technique to detect $P$. ultimum in soil.

P. ultimum was detected by PCR amplification in samples from which no Pythium species or other Pythium species were isolated on the selective medium for sugar beet and Chinese cabbage, respectively. The presence and growth of other Pythium species or microorganisms may interfere with the isolation of $P$. ultimum on the media. In addition, the results suggest that isolation on a selective medium is less sensitive than the PCR technique. However, the bands may correspond to a non- specific reaction of the primers, although the size of the PCR products was identical with that from $P$. ultimum. Further experiments will be needed to verify the value of these species-specific primers by using additional isolates of other Pythium species.

\section{ACKNOWLEDGMENTS}

We thank T. Ichitani for supplying the isolates of Pythium aphanidermatum, $P$. ultimum, and $P$. vanterpoolii.

\section{LITERATURE CITED}

1. Ali-Shtayeh, M. S., Len, L. C., and Dick, M. W. 1986. An improved method and medium for quantitative estimates of populations of Pythium species from soil. Trans. Br. Mycol. Soc. 86:39-47.

2. Amouzou-Alladaye, E., Dunez, J., and Clerjeau, M. 1988. Immunoenzymatic detection of Phytophthora fragariae in infected strawberry plants. Phytopathology 78:1022-1026.

3. Avila, F. J., Yuen, G. Y., and Klopfenstein, N. B. 1995. Characterization of a Pythium ultimum-specific antigen and factors that affect its detection using a monoclonal antibody. Phytopathology 85:1378-1387.

4. Beck, J. J., and Ligon, J. M. 1995. Polymerase chain reaction assays for the detection of Stagonospora nodorum and Septoria tritici in wheat. Phytopathology 85:319-324.

5. Braithwaite, K. S., Egeskov, N. M., and Smith, G. R. 1995. Detection of sugarcane bacilliform virus using the polymerase chain reaction. Plant Dis. 79:792-796.

6. Chen, W. 1992. Restriction fragment length polymorphisms in enzymatically amplified ribosomal DNAs of three heterothallic Pythium species. Phytopathology 82:1467-1472.

7. Chen, W., and Hoy, J. W. 1993. Molecular and morphological comparison of Pythium arrhenomanes and P. graminicola. Mycol. Res. 97:1371-1378.

8. Chen, W., Hoy, J. W., and Schneider, R. W. 1992. Species-specific polymorphisms in transcribed ribosomal DNA of five Pythium species. Exp. Mycol. 16:22-34.

9. Curran, J., Driver, F., Ballard, J. W. O., and Milner, R. J. 1994. Phylogeny of Metarhizium: Analysis of ribosomal DNA sequence data. Mycol. Res. 98:547-552.

10. De Boer, S. H., and Ward, L. J. 1995. PCR detection of Erwinia carotovora subsp. atroseptica associated with potato tissue. Phytopathology 85:854-858.

11. Dick, M. W. 1990. Key to Pythium. Department of Botany, University of Reading, Reading, UK. pp. 1-64.

12. Doss, R. P., and Welty, R. E. 1995. A polymerase chain reaction-based procedure for detection of Acremonium coenophialum in tall fescue. Phytopathology 85:913-917.

13. Francis, D. M., and St. Clair, D. A. 1993 Outcrossing in the homothallic oomycete, Pythium ultimum, detected with molecular markers. Curr. Genet. 24:100-106.

14. Goodwin, P. H., Hsiang, T., Xue, B. G., and Liu, H. W. 1995. Differentiation of Gaeumannomyces graminis from other turf-grass fungi by amplification with primers from ribosomal internal transcribed spacer. Plant Pathol. 44:384-391.

15. Hendrix, F. F., Jr., and Campbell, W. A. 1973. Pythiums as plant pathogens. Annu. Rev. Phytopathol. 11:77-98.

16. Hendrix, F. F., Jr., and Papa, K. E. 1974 Taxonomy and genetics of Pythium. Proc. Am. Phytopathol. Soc. 1:200-207.

17. Henson, J. M., Goins, T., Grey, W., Mathre, D. E., and Elliott, M. L. 1993. Use of polymerase chain reaction to detect Gaeumannomyces graminis DNA in plants grown in artificially and naturally infested soil. Phytopathology 83:283-287.

18. Kageyama, K., Tachi, M., Umetsu, M., and Hyakumachi, M. 1996. Epidemiology of $P y$ thium sulcatum associated with brown-blotted root rot of carrots. Ann. Phytopathol. Soc. Jpn. 62:130-133.

19. Kageyama, K., and Ui, T. 1980. A selective medium for isolation of Pythium spp. Ann. Phytopathol. Soc. Jpn. 46:542-544.

20. Kageyama, K., and Ui, T. 1981. Pythium species isolated from bean plants and soils in the experimental plots of monoculture and rotation. Ann Phytopathol. Soc. Jpn. 47:313 319.

21. Kageyama, K., Ui, T., and Narita, Y. 1981. Influence of Pythium spp. on the injury by bean monoculture. Ann. Phytopathol. Soc Jpn. 47:320-326.

22. Klassen, G. R., Balcerzak, M., and de Cock, A. W. A. M. 1996. 5S ribosomal RNA gene spacers as species-specific probes for eight species of Pythium. Phytopathology 86:581587.

23. Kreader, C. A. 1996. Relief of amplification inhibition in PCR with bovine serum albumin of T4 gene 32 protein. Appl. Environ. Microbiol. 62:1102-1106.

24. Lee, S. B., and Taylor, J. W. 1990. Isolation of DNA from fungal mycelia and single spores. Pages 282-287 in: PCR Protocols: A Guide to 
Methods and Applications. M. A. Innis, D. H. Gelfand, J. J. Sninsky, and T. J. White, eds. Academic Press, New York.

25. Lee, S. B., and Taylor, J. W. 1992. Phylogeny of five fungus-like protoctistan Phytophthora species, inferred from the internal transcribed spacers of ribosomal DNA. Mol. Biol. Evol. 9:636-653

26. Levesque, A. C., Vrain, C. T., and De Boer, S. H. 1994. Development of a species-specific probe for Pythium ultimum using amplified ribosomal DNA. Phytopathology 84:474-478.

27. Li, X., and De Boer, S. H. 1995. Selection of polymerase chain reaction primers from an RNA intergenic spacer region for specific detection of Clavibacter michiganensis subsp. sepedonicus. Phytopathology 85:837-842.

28. Lovic, B. R., Martyn, R. D., and Miller, M. E. 1995. Sequence analysis of the ITS region of rDNA in Monosporascus spp. to evaluate its potential for PCR-mediated detection. Phytopathology 85:655-661.

29. Martin, F. N. 1990. Taxonomic classification of asexual isolates of Pythium ultimum based on cultural characteristics and mitochondrial DNA restriction patterns. Exp. Mycol. 14:4756.

30. Martin, F. N. 1991. Selection of DNA probes useful for isolate identification of two $P y$ thium spp. Phytopathology 81:742-746.
31. Moukhamedov, R., Hu, X., Nazar, R. N., and Robb, J. 1994. Use of polymerase chain reaction-amplified ribosomal intergenic sequences for the diagnosis of Verticillium tricorpus. Phytopathology 84:256-259.

32. Nazar, R. N., Hu, X., Schmidt, J., Culham, D., and Robb, J. 1991. Potential use of PCR-amplified ribosomal intergenic sequences in the detection and differentiation of verticillium wilt pathogens. Physiol. Mol. Plant Pathol. 39:1-11.

33. O'Donnell, K. 1992. Ribosomal DNA internal transcribed spacer are highly divergent in the phytopathogenic ascomycete Fusarium sambucinum (Gibberella pulicaris). Curr. Genet. 22:213-220.

34. Plaats-Niterink, A. J. van der. 1981. Monograph of the genus Pythium. Studies in Mycology, No. 21. Centraalbureau Voor Schimmelcultures, Baarn, Netherlands.

35. Sanger, F., Nicklen, S., and Coulson, A. R. 1977. DNA sequencing with chain-terminating inhibitors. Proc. Natl. Acad. Sci. USA. 74:5463-5467.

36. Saunders, G. A., and Hancock, J. G. 1994. Self-sterile isolates of Pythium mate with selffertile isolates of Pythium ultimum. Mycologia 86:660-666.

37. Schilling, A. G., Moller, E. M., and Geiger, H. H. 1996. Polymerase chain reaction-based as- say for species-specific detection of Fusarium culmorum, $F$. graminearum, and $F$ avenaceum. Phytopathology 86:515-522.

38. Sherriff, C., Whelan, M. J., Arnold, G. M., and Bailey, J. A. 1995. rDNA sequence analysis confirms the distinction between Colletotrichum graminicola and C. sublineolum. Mycol. Res. 99:475-478.

39. Slack, S. A., Drennan, J. L., Westra, A. A. G., Gudmestad, N. C., and Oleson, A. E. 1996 Comparison of PCR, ELISA, and DNA hybridization for the detection of Clavibacter michiganensis subsp. sepedonicus in fieldgrown potatoes. Plant Dis. 80:519-524.

40. Sreenivasaprasad, S., Mills, P. R., and Brown, A. E. 1994. Nucleotide sequence of the rDNA spacer 1 enables identification of isolates of Colletotrichum as C. acutatum. Mycol. Res. 98:186-188.

41. White, T. J., Bruns, T., Lee, S., and Taylor, J. 1990. Amplification and direct sequencing of fungal ribosomal RNA genes for phylogenetics. Pages 315-322 in: PCR Protocols: A Guide to Methods and Applications. M. A Innis, D. H. Gelfand, J. J. Sninsky, and T. J. White, eds. Academic Press, New York.

42. Yuen, G. Y., Craig, M. L., and Avila, F. 1993. Detection of Pythium ultimum with a speciesspecific monoclonal antibody. Plant Dis. 77:692-698. 